\title{
Basic Properties of Calcined Underground Ant Nest Materials and Its Influence on the Compressive Strength of Concrete
}

\author{
Wei Zhou(D, Peng Zhu and Wenjun Qu* \\ Department of Structural Engineering, Tongji University, Shanghai 200092, China; \\ wei.zhou@hotmail.com (W.Z.); pzhu@tongji.edu.cn (P.Z.) \\ * Correspondence: quwenjun.tj@tongji.edu.cn; Tel./Fax: +86-21-65980321
}

Received: 20 March 2019; Accepted: 9 April 2019; Published: 11 April 2019

check for updates

\begin{abstract}
Underground ant nests are typically made of soil and rubble mixed with dead plant bodies, ant secretions, and other organic substances. The clay content is high, and the natural clay materials show pozzolanic activity after calcination. In this study, the underground ant nest materials of Iridomyrmex anceps, which is a common ant in the Shanghai area, are calcined and ground, and the material properties of calcined ant nest clay powder (CANCP) are characterized from six aspects: chemical composition, particle morphology, specific gravity, specific surface area, particle size distribution and pozzolanic activity index. The pozzolanic activity of CANCP is evaluated by the strength contribution rate of pozzolanic activity, revealing that CANCP is beneficial to the strength of the mortar system from an early age. The influence of CANCP on the compressive strength of concrete is analyzed using three aspects, namely, content, curing age and calcination temperature, and it is found that the three aspects of CANCP have a strong influence on the compressive strength of concrete.
\end{abstract}

Keywords: underground ant nest; calcination; calcined ant nest clay powder (CANCP); pozzolanic activity; strength contribution rate of pozzolanic; compressive strength

\section{Introduction}

Ants are excellent architects in the animal world; their nests contain unique structures that feature excellent heat preservation, moisture retention and ventilation function. However, ants have strict demands on the building materials of nests, such as the soil particle size, weight, luster and color. Underground ant nests are typically made of soil and rubble mixed with dead plant bodies, ant secretions and other organic substances, and the content of clay is high. The clay of underground ant nests is composed of earth particles cemented together to form a hard brick-like material. Natural clays typically contain a mixture of clay minerals associated with non-clay minerals. Most natural pozzolans develop their activity from clay minerals such as kaolinite, montmorillonite, and illite. Each type of clay has an optimum calcination temperature range that causes the breakdown of the crystalline structure of the clay and the formation of amorphous silica and alumina [1]. Some pozzolanic active substances are suitable for partial replacement of cement and are natural products, such as pozzolan [2,3], zeolite, and solid waste, industrial by-products, such as slag, fly ash, silica fume, rice husk ash, waste glass [4], broken ceramics [5] and clay brick [6], or low energy products, such as calcined clay [7-9] and calcined termite clay [1].

Ants change the physical characteristics of the soil through nesting activities [10], which can result in nutrient redistribution in the soil profile [11,12], increased soil porosity, improved soil water conductivity and permeability, increased soil water retention capacity [13], altered soil bulk density [14], 
improved electrical conductivity, and increased soil nutrient content and potential for higher crop yield [15]. Underground ant nests also influence the chemical properties of soil; such nests can increase the concentration of organic matter, the N, P and K content [16], and the concentration of $\mathrm{K}^{+}, \mathrm{Na}^{+}, \mathrm{Ca}^{2+}$, and $\mathrm{Mg}^{2+}$ ions in anthills [17] and alter the anthill's $\mathrm{pH}$ [18]. Through decomposition of plant residues, ant activity can promote the release of $\mathrm{N}$, decomposition of organic matter, and mineral and nutrient cycling in plant residues [19]. Such activity can also increase soil organic matter, particularly stable humic acid, which is conducive to the stability of the soil structure and soil fertility [20]. Ant activity can also stimulate $\mathrm{CO}_{2}$ production [21] and soil organic $\mathrm{N}$ mineralization and increase denitrification in soil [22]. Through nitrogenase activity, ants can contribute $N$ to their habitat [23]. Thus, relative to surrounding ordinary clay, the physical properties and chemical properties of underground ant nest materials are strongly altered. In the present work, we study the basic properties of underground ant nest materials after calcination, and we explore and summarize the material properties of calcined ant nest clay powder (CANCP) using six aspects: the chemical composition, particle morphology analysis, specific gravity, specific surface area, particle size distribution and pozzolanic activity index. The paper discusses whether underground ant nest materials after calcination can partially replace the pozzolanic active substance in cement and the associated influence on the compressive strength of concrete.

\section{Properties of Calcined Underground Ant Nest Materials}

\subsection{Collection and Calcination of an Underground Ant Nest}

Iridomyrmex anceps belongs to the Iridomyrmex category and is distributed across China. Ant nests are underground, and anthills consists of soil particles, the Pinus massoniana male flower, grass, and frass. Anthills are packed into a grave shape, spherical shape, or irregular shape. In this study, the underground nests of Iridomyrmex anceps were sampled from three locations.

The optimum calcination temperature and time of clay minerals depends on the types of clay minerals, and clay can exhibit potential pozzolanic properties when treated under appropriate calcination temperatures and times. Clay has the greatest activity when it is calcined at $600-800{ }^{\circ} \mathrm{C}$ [24]. Thus, $600{ }^{\circ} \mathrm{C}$ and $800{ }^{\circ} \mathrm{C}$ were used as the control temperatures for calcination tests. Clay calcined for approximately $1-3 \mathrm{~h}$ at controlled temperature has the highest activity [25]; thus, $2 \mathrm{~h}$ was used as the calcination control time. The underground ant nest material was sampled in batches of $50 \mathrm{~kg}$, and impurities such as plant dead bodies were removed before preliminary grinding. Samples were placed in a box-type resistance furnace, and four groups of temperature sensors were embedded in the upper, middle and lower parts of the ant nest soil to record temperature changes. The ant nest soil was dark-brown and granular after initial treatment. After calcination at different temperatures, the ant nest soil color changed to brick red due to the conversion of $\mathrm{FeO}$ to $\mathrm{Fe}_{2} \mathrm{O}_{3}$ at high temperature under aerobic conditions. The ant nest soil quality at $600{ }^{\circ} \mathrm{C}$ and $800{ }^{\circ} \mathrm{C}$ after calcination led to masses of $39.25 \mathrm{~kg}$ and $38.74 \mathrm{~kg}$ and a loss on ignition of $21.5 \%$ and $22.5 \%$, respectively.

\subsection{Material Properties of $C A N C P$}

An SM-500 ball crusher was used for milling of the ant nest soil for $60 \mathrm{~min}$ after calcination. The chemical composition of CANCP was analyzed using an $\mathrm{X}$-ray fluorescence spectrometer. The total content of $\mathrm{SiO}_{2}, \mathrm{Al}_{2} \mathrm{O}_{3}$ and $\mathrm{Fe}_{2} \mathrm{O}_{3}$ in $800{ }^{\circ} \mathrm{C} \mathrm{CANCP}$ and $600{ }^{\circ} \mathrm{C} \mathrm{CANCP}$ reached $88.76 \%$ and $83.37 \%$, respectively, both greater than the $70 \%$ specified in the ASTM standard for concrete mineral admixtures [26]. The results are shown in Table 1 . The active component in $800^{\circ} \mathrm{C} \mathrm{CANCP}$ is greater than that of $600{ }^{\circ} \mathrm{C} \mathrm{CANCP}$; thus, $800^{\circ} \mathrm{C} \mathrm{CANCP}$ was used as the reference to test the material properties of CANCP. Many tests showed that the active component of ordinary calcined clay was $80-85 \%$, while the active component in $800{ }^{\circ} \mathrm{C} \mathrm{CANCP}$ was close to $90 \%$, superior to that of ordinary calcined clay [27-30]. 
Table 1. Chemical composition of materials (\%) (calcined ant nest clay powder, CANCP).

\begin{tabular}{ccccccccc}
\hline Constituent & $\mathrm{SiO}_{\mathbf{2}}$ & $\mathbf{A l}_{\mathbf{2}} \mathbf{O}_{\mathbf{3}}$ & $\mathrm{Fe}_{\mathbf{2}} \mathbf{O}_{\mathbf{3}}$ & $\mathbf{C a O}$ & $\mathbf{K}_{\mathbf{2}} \mathbf{O}$ & $\mathbf{M g O}$ & $\mathbf{N a}_{2} \mathbf{O}$ & $\mathbf{S O}_{3}$ \\
\hline Cement & 23.25 & 7.79 & 2.41 & 46.78 & 0.574 & 0.459 & 0.574 & 4.10 \\
Fly ash & 47.14 & 22.67 & 1.02 & 4.28 & 0.721 & 6.25 & 0.468 & 2.3 \\
Recycled powder & 53.8 & 13.2 & 5.15 & 13.6 & 2.77 & 2.58 & 0.65 & 0.68 \\
$800^{\circ} \mathrm{C}$ CANCP & 69.5 & 14.1 & 5.16 & 2.27 & 2.81 & 2.24 & 1.34 & 0.14 \\
$600{ }^{\circ} \mathrm{C}$ CANCP & 64.4 & 13.8 & 5.17 & 2.24 & 2.77 & 2.14 & 1.18 & 0.14 \\
\hline
\end{tabular}

After two tests, the margin of $45 \mu \mathrm{m}$ square hole sieves was measured as $16.25 \%$ and $16.58 \%$, close to the $12 \%$ requirement of first-grade fly ash [31]. The specific gravity of CANCP is 2.66 , and the specific surface area is $491 \mathrm{~m}^{2} / \mathrm{kg}$. Figure 1 shows SEM micrographs of CANCP at different magnifications. From the particle morphology, CANCP is clearly different from the regular spherical particles of fly ash; most of its particles are angular, and the shape of the structure is not strongly regular, but the particle size distribution is even. As shown in the high-magnification electron micrographs, these particles have cleavage planes, and some fine particles are attached to the surface. This finding indicates that the interior contains some mineral elements that are prone to cleavage and will affect the fluidity of concrete. Through water requirement ratio tests, the water requirement ratio for CANCP is $110 \%$ and slightly larger than that of cement. This characteristic has little effect on the flowability of the mixture, and the flowability is slightly worse.

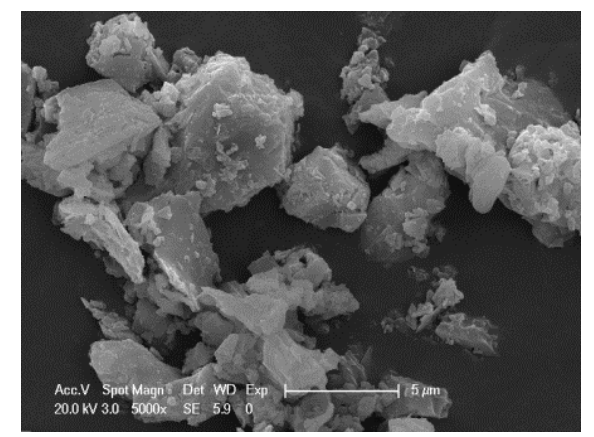

(a)

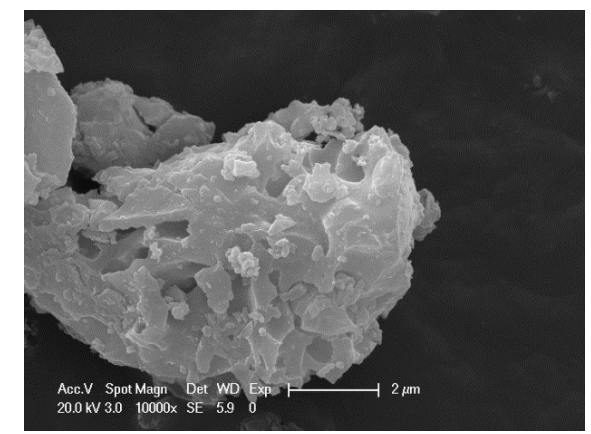

(b)

Figure 1. (a) 5000× and (b) 10,000× CANCP SEM micrographs (calcined ant nest clay powder, CANCP).

The particle size distribution of CANCP was determined using a Winner laser particle size analyzer. The results are shown in Figure 2. The average particle size of CANCP was $23.35 \mu \mathrm{m}$, and most particles were smaller than $50 \mu \mathrm{m}$. The particles with sizes 1-10 $\mu \mathrm{m}$ composed a large proportion, and the gradation exhibited continuity. A smaller particle size is better for stimulating the activation of materials; thus, the presence of 1-10 $\mu \mathrm{m}$ particles in a large proportion is favorable for maximizing activity.

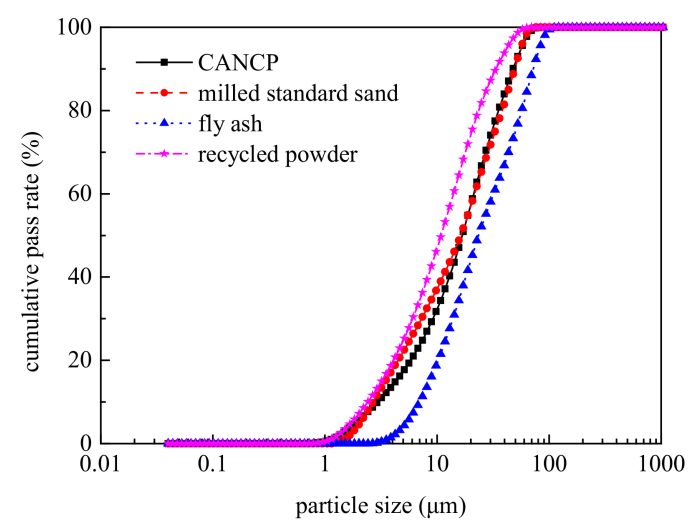

Figure 2. Particle size distribution curves of various materials. 


\subsection{Pozzolanic Activity Index of CANCP}

The pozzolanic activity index of CANCP of $800{ }^{\circ} \mathrm{C}$ calcination was evaluated using two methods: the lime absorption method (direct) and the strength index method (indirect).

\subsubsection{Lime Absorption Method}

The lime absorption method involves mixing a pozzolanic material with a Portland cement slurry or a saturated lime solution, and the activity of pozzolanic material is quantitatively evaluated by measuring the concentrations of residual $\mathrm{Ca}^{2+}$ and $\mathrm{OH}^{-}$in solutions of different ages. Lower concentrations of $\mathrm{Ca}^{2+}$ and $\mathrm{OH}^{-}$indicate higher pozzolanic activity [32]. The activity of pozzolanic materials such as fly ash [33], metakaolin [34], and clay brick powder [35] has previously been evaluated using the lime absorption method. Two CANCP samples were taken at random, according to GB/T 18736-2002 [36], and the Portland cement and CANCP were mixed at a 7:3 mass ratio. Two CANCP sample test results were marked on the pozzolanic activity graph, both falling below the curve in the graph (solubility curves of $\mathrm{Ca}(\mathrm{OH})_{2}$ at $40{ }^{\circ} \mathrm{C}$ ). Thus, CANCP material has pozzolanic activity; see Figure 3.

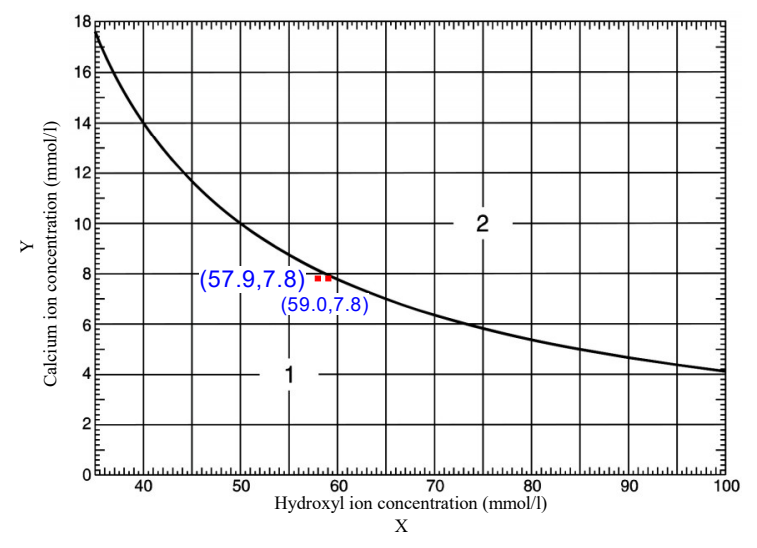

Figure 3. Evaluation of pozzolanic activity graph.

\subsubsection{Strength Index Method}

The strength index method compares the 28 days compressive strength of the contrast mortar of a certain mineral admixture with an equal mass of cement to that of a reference mortar, and the ratio of these two compressive strengths is defined as the activity index of the composite mineral admixture. Among all mineral admixtures, fly ash is the most commonly used and systematically characterized, and recycled powder can be used to grind waste sintered clay brick to a certain fineness, similar to CANCP; fly ash can also be treated through clay calcination and grinding processes. A comparison of the two types of materials would be meaningful; thus, according to GB/T 18736-2002 [36], CANCP mortar (CAP) and five groups of contrast mortar was designed: reference mortar $\mathrm{CT}$, reference mortar SS, milled standard sand mortar GSS, fly ash mortar FA and recycled powder mortar RP.

\section{Materials}

PO 42.5 ordinary Portland cement conforming to GB175-2007 [37] was used; the chemical composition and physical and mechanical properties are listed in Tables 1 and 2, respectively. The fly ash used in this test was second-grade fly ash produced by the first power plant of Shanghai. The quality of the fly ash was in accordance with GB/T1596-2017 [31], and the chemical composition and physical and mechanical properties are listed in Tables 1 and 3, respectively. 
Table 2. Physical and mechanical properties of Portland cement.

\begin{tabular}{cccccccc}
\hline \multirow{2}{*}{$\begin{array}{c}\text { Fineness } \\
(\%)\end{array}$} & $\begin{array}{c}\text { Density } \\
\left(\mathbf{g} / \mathbf{c m}^{3}\right)\end{array}$ & \multicolumn{2}{c}{ Setting Time (min) } & \multicolumn{2}{c}{ Flexural Strength (MPa) } & \multicolumn{2}{c}{$\begin{array}{c}\text { Compressive } \\
\text { Strength (MPa) }\end{array}$} \\
\cline { 3 - 8 } & & Initial Setting & Final Setting & 3 Days & 28 Days & 3 Days & 28 Days \\
\hline 5.7 & 3.13 & 150 & 490 & 5.5 & 7.6 & 24.6 & 44.3 \\
\hline
\end{tabular}

Table 3. Physical and mechanical properties of fly ash (\%).

\begin{tabular}{cccc}
\hline Fineness & Water Requirement Ratio & Water Content & Loss on Ignition \\
\hline 18.8 & 92 & 0.2 & 6.9 \\
\hline
\end{tabular}

Recycled powder in this study was prepared by smashing, grinding, drying and grading abandoned clay bricks and cement solids. The chemical composition and physical and mechanical properties are listed in Tables 1 and 4, respectively. Its density is $2.63 \mathrm{~g} / \mathrm{cm}^{3}$, and the average particle size is $16.14 \mu \mathrm{m}$.

Table 4. Physical and mechanical properties of recycled powder (\%).

\begin{tabular}{ccccc}
\hline Loss on Ignition & Water Content & Soundness $(\mathbf{m m})$ & Free Calcium Oxide & Water Requirement Ratio \\
\hline 5.9 & 0.5 & 0.5 & 0.35 & 105 \\
\hline
\end{tabular}

The standard sand was ISO679 standard sand. Milled standard sand was obtained by ball milling of the ISO standard sand for $2 \mathrm{~h}$ with a SM-500 ball mill, and the sieving test was performed using a FSY-150E cement fineness negative-pressure sieve analyzer. The margin of a $45 \mu \mathrm{m}$ square hole sieve was $17.55 \%$, the fineness control requirements are close to that of CANCP, and the average size of the ground standard sand was $23.29 \mu \mathrm{m}$. The particle size distributions of CANCP, fly ash, recycled powder, and milled standard sand are plotted in Figure 2. The particle size distribution of CANCP, fly ash, recycled powder, and milled standard sand show few differences. The size distribution curve of CANCP is close to that of milled standard sand, and the curves even overlap in some regions; thus, the fineness of the two is relatively close, and both approach the fineness control requirements for first-grade fly ash.

Specimen Preparation and Mixing Design

Specimens for strength index tests were prepared following GB/T17671-1999 [38]. The cementitious materials were mixed for $1 \mathrm{~min}$ in the mixer. Then, $70 \%$ water was added and mixed for $3 \mathrm{~min}$. The sand was added and mixed for $1 \mathrm{~min}$. The remaining 30\% water was added and mixed for $5 \mathrm{~min}$. The mixture was poured into molds measuring $40 \mathrm{~mm} \times 40 \mathrm{~mm} \times 160 \mathrm{~mm}$ and consolidated using a vibration table. The specimens were maintained in the standard curing case (temperature $20 \pm 1{ }^{\circ} \mathrm{C}$ and moisture above $90 \%$ ) for $24 \mathrm{~h}$. After demolding, the specimens were kept in the curing room (temperature $20 \pm 2{ }^{\circ} \mathrm{C}$ and moisture above $50 \%$ ) in preparation for further tests.

The mass mix ratio of reference mortar CT was one part cement, three parts standard sand and half-part water. The reference mortar SS used standard sand instead of 30\% quality cement, and the milled standard sand mortar GSS used milled standard sand instead of 30\% quality cement. The replacement amount of other pozzolanic ash materials was 30\%. The mix design was modified as shown in Table 5. 
Table 5. Proportion of mortar in each group $(\mathrm{g})$.

\begin{tabular}{cccccccc}
\hline $\begin{array}{c}\text { Types of } \\
\text { Mortar }\end{array}$ & Cement & $\begin{array}{c}\text { Standard } \\
\text { Sand }\end{array}$ & Water & $\begin{array}{c}\text { Milled } \\
\text { Standard Sand }\end{array}$ & $\begin{array}{c}\text { Fly } \\
\text { Ash }\end{array}$ & $\begin{array}{c}\text { Recycled } \\
\text { Powder }\end{array}$ & CANCP \\
\hline CT & 450 & 1350 & 225 & - & - & - & - \\
SS & 315 & 1485 & 225 & - & - & - & - \\
GSS & 315 & 1350 & 225 & 135 & - & - & - \\
FA & 315 & 1350 & 225 & - & 135 & - & - \\
RP & 315 & 1350 & 225 & - & - & 135 & - \\
CAP & 315 & 1350 & 225 & - & - & - & 135 \\
\hline
\end{tabular}

Test Methods

The CANCP mortar and contrast mortar of each group were cured for 3 days, 7 days, 28 days and 90 days to test their flexural strength and compressive strength following GB/T17671-1999 [38]. Flexural specimens were tested at a loading rate of $50 \mathrm{~N} / \mathrm{s}$. The specimens were loaded from their mid-span, and the clear distance between simple supports was $100 \mathrm{~mm}$. The two broken pieces remaining after the flexural test were subjected to compressive strength tests at a loading rate of $2500 \mathrm{~N} / \mathrm{s}$. Three specimens were tested for flexural strength. The average of six specimens was used to evaluate the compressive strength of the mixtures.

Results and Discussion

The test results are shown in Table 6. The relationship between the compressive strengths of the CANCP mortar and the reference mortar, and CANCP mortar and the contrast mortar are shown in Figure 4.

Table 6. Flexural and compressive strength of mortar in each group (g).

\begin{tabular}{cccccccccc}
\hline \multirow{2}{*}{$\begin{array}{c}\text { Mortar } \\
\text { Type }\end{array}$} & \multicolumn{3}{c}{ Flexural Strength (MPa) } & \multicolumn{3}{c}{ Compressive Strength (MPa) } & $\begin{array}{c}\text { Strength Index } \\
\mathbf{( 2 8} \text { Days) (\%) }\end{array}$ \\
\cline { 2 - 10 } & 3 Days & 7 Days & 28 Days & 90 Days & 3 Days & 7 Days & 28 Days & 90 Days & - \\
\hline CT & 5.23 & 6.40 & 7.73 & 9.73 & 28.18 & 38.85 & 51.92 & 62.15 & 100.0 \\
SS & 3.47 & 4.70 & 5.23 & 6.57 & 15.48 & 20.54 & 25.47 & 34.15 & 49.1 \\
GSS & 4.60 & 5.64 & 6.27 & 7.40 & 22.35 & 25.30 & 33.28 & 43.75 & 64.1 \\
FA & 3.93 & 5.27 & 7.20 & 9.47 & 18.88 & 28.20 & 37.33 & 53.68 & 71.9 \\
RP & 4.43 & 5.53 & 6.55 & 8.20 & 22.23 & 28.15 & 37.03 & 47.83 & 71.3 \\
CAP & 4.27 & 5.20 & 6.70 & 8.67 & 19.46 & 27.52 & 39.60 & 50.53 & 76.3 \\
\hline
\end{tabular}

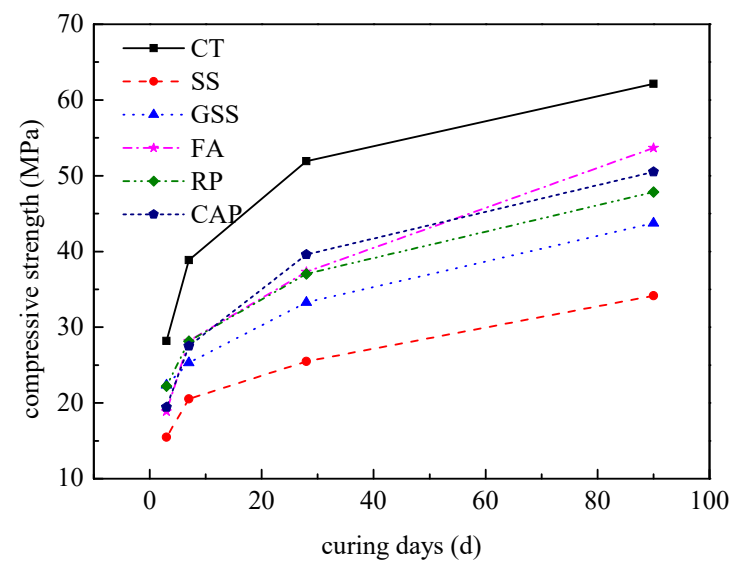

Figure 4. Relationship between the compressive strength of CANCP mortar, reference mortar and contrast mortar.

The reference mortar SS uses standard sand instead of cement of the same quality because the standard sand has no pozzolanic activity and because the filling action is weak; thus, the amount of 
cement decreases. This condition directly results in decreased compressive strength in the mortar, and thus the compressive strength is lower than that of the other mortar after 3 days. The mortar GSS uses milled standard sand instead of cement of the same quality. Milled standard sand also has no pozzolanic activity, but its compressive strength is higher than that of the reference mortar (SS); thus, the micro-filling effect of milled standard sand plays an active role. The compressive strength of CANCP mortar begins to exceed mortar GSS at 7 days, as shown in Figure 2. The fineness of the milled standard sand is essentially the same as that of CANCP, and the filling effect of cement mortar system is also essentially the same. Therefore, CANCP not only provides filling action but also has pozzolanic activity and participates in the hydration reaction of cement. Figure 4 also indicates that the early compressive strength of CANCP mortar is slightly lower than that of mortar FA and mortar RP; the compressive strength at 28 days is higher than that of mortar FA and mortar RP; and the compressive strength at 90 days is higher than that of mortar RP and less than that of mortar FA.

The activity index of CANCP, fly ash and recycled powder was 76.3, 71.9 and 71.3, respectively, and the activity index of CANCP was larger than that of fly ash and recycled powder and greater than the value of 65 specified in the GB/T2847-2005 standard [39]. These results show that CANCP has pozzolanic activity and meets the requirements for an active admixture.

The pozzolanic activity index obtained from the compressive strength ratio reflects only whether the admixture has pozzolanic activity; the index does not reflect the extent of pozzolanic activity of the admixture. Pu Xincheng [40] introduced the concept of a specific strength of concrete and cement, i.e., the contribution of a unit amount of cement to the strength of concrete, and analyzed the pozzolanic effect of admixtures in concrete. The principle is as follows:

(1) The concrete compressive strength ratio of the mineral admixture $R_{r a}$, i.e., the strength contribution of unit cement to concrete, is defined as follows:

$$
R_{r a}=\frac{R_{a}}{q}
$$

In this expression, $R_{r a}$ is the specific strength of concrete containing an admixture (MPa), $R_{a}$ is the absolute value of the strength of concrete containing an admixture (MPa), and $q$ is the percentage of cement content in the concrete cementitious material.

(2) The specific strength of reference concrete without mineral admixture $R_{r r}$ is defined as follows:

$$
R_{r r}=\frac{R_{r}}{100}
$$

In the expression: $R_{r r}$ is the specific strength of concrete (MPa); $R_{a}$ is the absolute value of the strength of concrete.

(3) The difference between $R_{r r}$ and $R_{r a}$ is the specific strength of the pozzolanic effect contribution:

$$
R_{r p}=R_{r a}-R_{r r}
$$

$R_{r p}$ reflects the contribution of the pozzolanic effect of mineral admixtures to the strength of the entire system. A negative value shows that mineral admixtures reduce the strength.

(4) The strength contribution rate of cement hydration reaction $P_{h}$ is defined as follows:

$$
p_{h}=\frac{R_{r r}}{R_{r a}} \times 100 \%
$$

The strength contribution rate of the pozzolanic effect $P_{p}$ is defined as follows:

$$
P_{p}=\frac{R_{r p}}{R_{r a}} \times 100 \%=\frac{R_{r a}-R_{r r}}{R_{r a}} \times 100 \%
$$


The pozzolanic activity of CANCP, standard sand, milled standard sand, fly ash, and recycled powder was evaluated using this method. The results are shown in Table 7.

Table 7. Strength contribution rate of the pozzolanic effect.

\begin{tabular}{cccccc}
\hline \multirow{2}{*}{ Curing Time } & \multicolumn{5}{c}{ Powder Type } \\
\cline { 2 - 6 } & SS & GSS & FA & RP & CAP \\
\hline 3 days & -27.42 & 11.73 & -4.47 & 11.27 & 1.38 \\
7 days & -32.40 & -4.04 & 1.05 & 3.39 & 1.17 \\
28 days & -42.70 & -9.20 & 2.66 & 1.87 & 8.23 \\
90 days & -27.39 & 0.56 & 18.96 & 11.93 & 13.91 \\
\hline
\end{tabular}

The strength contribution rate of the pozzolanic effect of mortar SS was negative for all ages, and the standard sand had no pozzolanic activity. Thus, standard sand instead of equal-quality cement reduces the strength of cement mortar. The 3 days strength contribution rate of the pozzolanic effect of mortar GSS is 11.73 because it has no pozzolanic activity. For intuitive comparison, the pozzolanic effect strength contribution rate is used to describe its strength in cement paste, and the strength of the pozzolanic effect at this time is contributed by the filling effect of the milled standard sand. The strength contribution rate of the pozzolanic effect of mortar GSS is zero or negative with increasing age, indicating that when milled standard sand is replaced by equal-quality cement, the strength of the cement mortar can decrease, and the contribution of the filling effect of milled standard sand to the strength of the cement mortar appears primarily at early ages.

The strength contribution rate of the pozzolanic effect of mortar FA increases with age, and the 3 days strength contribution rate of the pozzolanic effect of mortar FA is negative. This result shows that fly ash has an adverse effect on the early strength of the complete mortar system. The strength contribution rate of the pozzolanic effect is positive starting from the age of 7 days, and the fly ash begins to have a beneficial effect on the strength of the entire mortar system; the 90 days strength contribution rate of the pozzolanic effect of mortar FA is 18.96. The strength contribution rate of the pozzolanic effect of the recycled powder RP is positive at all ages, and the 3 days strength contribution rate of pozzolanic effect is as high as 11.27. Thus, the beneficial influence of recycled powder on the entire mortar system is reflected primarily in the early strength, and the 90 days strength contribution rate of pozzolanic effect is 11.93 , with a long-term pozzolanic effect that is less than that of fly ash. The strength contribution rate of the pozzolanic effect of mortar CAP increases with age and is positive. CANCP begins to show a favorable effect on the strength of the mortar system from an early age, and the 90 days strength contribution rate of the pozzolanic effect of mortar CAP is 13.91. The long-term pozzolanic effect of CANCP is larger than that of recycled powder but smaller than that of fly ash.

\section{Compressive Strength Test}

\subsection{Material}

PO 42.5 ordinary Portland cement conforming to GB175-2007 [37] was used; the chemical composition and physical and mechanical properties are listed in Tables 1 and 2, respectively. The fine aggregate consisted of natural river sand with a fineness modulus of 2.5, and the coarse aggregate consisted of $5 \mathrm{~mm}-25 \mathrm{~mm}$ continuous graded natural stones; its basic material properties are shown in Tables 8 and 9. The DY-106 polycarboxylate high-performance water-reducing agent was selected, and the performance parameters are shown in Table 10. 
Table 8. Basic material properties of the natural river sand.

\begin{tabular}{ccccc}
\hline Water Content (\%) & $\begin{array}{c}\text { Sediment } \\
\text { Percentage (\%) }\end{array}$ & $\begin{array}{c}\text { Apparent Density } \\
\left(\mathbf{k g} / \mathbf{m}^{\mathbf{3}}\right)\end{array}$ & $\begin{array}{c}\text { Compact Packing } \\
\text { Density }\left(\mathbf{k g} / \mathbf{m}^{\mathbf{3}}\right)\end{array}$ & $\begin{array}{c}\text { Loose Packing } \\
\text { Density }\left(\mathbf{k g} / \mathbf{m}^{\mathbf{3}}\right)\end{array}$ \\
\hline 2.0 & 1.5 & 2570 & 1760 & 1650 \\
\hline
\end{tabular}

Table 9. Basic material properties of the natural stone.

\begin{tabular}{cccccc}
\hline $\begin{array}{c}\text { Water Content } \\
(\mathbf{\%})\end{array}$ & $\begin{array}{c}\text { Sediment } \\
\text { Percentage (\%) }\end{array}$ & $\begin{array}{c}\text { Apparent } \\
\text { Density } \\
\mathbf{( k g / \mathbf { m } ^ { 3 } )}\end{array}$ & $\begin{array}{c}\text { Compact } \\
\text { Packing Density } \\
\mathbf{( k g / \mathbf { m } ^ { 3 } )}\end{array}$ & $\begin{array}{c}\text { Loose Packing } \\
\text { Density } \\
\mathbf{( k g / \mathbf { m } ^ { 3 } )}\end{array}$ & $\begin{array}{c}\text { Crushing } \\
\text { Value (\%) }\end{array}$ \\
\hline 0.8 & 0.9 & 2700 & 1430 & 1650 & 6.6 \\
\hline
\end{tabular}

Table 10. Performance parameters of the water-reducing agents.

\begin{tabular}{ccccccc}
\hline $\begin{array}{c}\text { Solid } \\
\text { Content (\%) }\end{array}$ & Density & pH & $\begin{array}{c}\text { Water-Reducing } \\
\text { Rate of Concrete } \\
\mathbf{( \% )}\end{array}$ & $\begin{array}{c}\text { Fluidity of } \\
\text { Cement } \\
\text { Paste (mm) }\end{array}$ & $\begin{array}{c}\text { Chloride } \\
\text { Ion Content } \\
\mathbf{( \% )}\end{array}$ & $\begin{array}{c}\text { Total } \\
\text { Alkalinity }\end{array}$ \\
\hline 40.19 & 1.090 & 6.0 & 30.0 & 285 & 0.05 & 1.2 \\
\hline
\end{tabular}

\subsection{Specimen Preparation and Mix Design}

A cubic specimen measuring $100 \mathrm{~mm} \times 100 \mathrm{~mm} \times 100 \mathrm{~mm}$ was used to study the compressive strength of concrete following GB/T 50081-2002 [41]. The mold was wiped clean, and a layer of release agent was painted on its inner surface before preparing the specimen. A vibrating table was used with a vibration frequency of $(50 \pm 3) \mathrm{Hz}$ and a no-load amplitude of $(0.5 \pm 0.1) \mathrm{mm}$. The molded concrete block was covered with an impervious film to prevent moisture from volatilization and placed in the indoor environment $\left(20 \pm 5^{\circ} \mathrm{C}\right)$ for $24 \mathrm{~h}$. The template was removed, and the test block was numbered.

In this experiment, $\mathrm{CT}$ was the reference concrete, i.e., ordinary concrete, and a standard mix proportion of design strength of C50 was selected. The calculated mix proportions for the ordinary concrete CT were (cement: water: sand: stone $=486: 170: 741: 1023$ ). For the other six sets of concrete, the total amount of cementitious material was $486 \mathrm{~kg} / \mathrm{m}^{3}$, the ratio of water to binder was 0.35 , and the sand content was $42 \%$. The CANCP with $800{ }^{\circ} \mathrm{C}$ calcination was used to replace cement in proportions of $5 \%, 10 \%, 15 \%, 20 \%$ and $30 \%$, and the CANCP with $600{ }^{\circ} \mathrm{C}$ calcination was used to replace cement in proportions of $10 \%$ to study the effect on concrete properties. By adjusting the dosage of water-reducing agent, concrete slump was controlled near $200 \mathrm{~mm}$. The mix proportion and concrete slump are shown in Table 11.

Table 11. Mix proportion and slump $\left(\mathrm{kg} / \mathrm{m}^{3}\right)$.

\begin{tabular}{ccccccccc}
\hline $\begin{array}{c}\text { Specimen } \\
\text { Number }\end{array}$ & Cement & $\begin{array}{c}\mathbf{8 0 0}{ }^{\circ} \mathbf{C} \\
\text { CANCP }\end{array}$ & $\begin{array}{c}\mathbf{6 0 0}^{\circ} \mathbf{C} \\
\text { CANCP }\end{array}$ & Sand & Stone & Water & $\begin{array}{c}\text { Water } \\
\text { Reducer }\end{array}$ & Slump \\
\hline $\mathrm{CT}$ & 486 & 0 & 0 & 741 & 1023 & 170 & 0.96 & 220 \\
$\mathrm{ZW}_{5}$ & 461.7 & 24.3 & 0 & 741 & 1023 & 170 & 0.97 & 220 \\
$\mathrm{ZW}_{10}$ & 437.4 & 48.6 & 0 & 741 & 1023 & 170 & 1.22 & 240 \\
$\mathrm{ZW}_{15}$ & 413.1 & 72.9 & 0 & 741 & 1023 & 170 & 1.99 & 220 \\
$\mathrm{ZW}_{20}$ & 388.8 & 97.2 & 0 & 741 & 1023 & 170 & 2.02 & 220 \\
$\mathrm{ZW}_{30}$ & 340.2 & 145.8 & 0 & 741 & 1023 & 170 & 2.21 & 220 \\
$Z \mathrm{ZW00}_{10}$ & 437.4 & 0 & 48.6 & 741 & 1023 & 170 & 1.01 & 230 \\
\hline
\end{tabular}

\subsection{Test Methods}

The compressive strength of concrete was tested following GB/T 50081-2002 [41]. The tests were performed immediately after curing for 3 days, 7 days, 14 days, 28 days and 90 days in the standard curing room. The test used a DY-3000DX electro-hydraulic servo microcomputer controlled 
pressure testing machine, and the loading rate was $0.5 \mathrm{MPa} / \mathrm{s}$. Six concrete blocks were used for each compression test, and the compressive strength was averaged.

\subsection{Results and Discussion}

\subsubsection{Influence of the Content of CANCP}

For a more intuitive observation and analysis of test results, the ratio of the compressive strength of concrete with varying CANCP content to the compressive strength of reference concrete was used as the relative compressive strength of CANCP concrete. The relationship between the compressive strength of concrete and the CANCP content is shown in Figure 5.

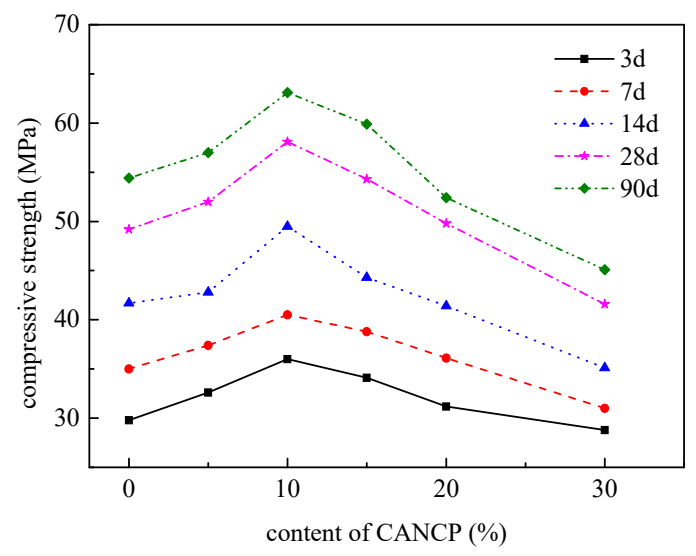

Figure 5. Relationship between the compressive strength of concrete and CANCP content.

The content of CANCP has a strong influence on the compressive strength of concrete. With increasing CANCP content, the cubic compressive strength of concrete first increases and then decreases. Each curve has a peak value, and the compressive strength of the concrete containing $10 \%$ CANCP is the largest. The compressive strength for curing times of 3 days, 7 days, 14 days, and 28 days increases by $20.8 \%, 15.5 \%, 18.9 \%$, and $18 \%$, respectively, and the early strength increases quickly. When the CANCP content is $20 \%$, the compressive strength of concrete is essentially identical to that of ordinary concrete CT without CANCP. When the CANCP content is more than $20 \%$, the compressive strength of concrete begins to decrease, and the compressive strength for 3 days, 7 days, 14 days, and 28 days curing is reduced by $3.2 \%, 1.6 \%, 15.8 \%$, and $15.4 \%$, respectively. The early strength decreases less. Adding CANCP to concrete can improve the strength of concrete, but the content should be less than $20 \%$. The optimum content in this experiment is $10 \%$ of the cementitious materials.

\subsubsection{Influence of Curing Age}

The development curves for the compressive strength of concrete containing varying CANCP content with age are shown in Figure 6.

The compressive strength of concrete containing various CANCP content increases with age. The development of early strength is faster, and the 3 days compressive strength reaches the 28 days strength of $60 \%$, the 14 days compressive strength reaches the 28 days strength of $85 \%$, and the compressive strength between 14 days and 28 days of curing is smaller; the 90 days compressive strength is more than 1.05 times the strength at 28 days. To characterize the changes in the compressive strength of $\mathrm{CANCP}$ concrete with age, the relative compressive strength of CANCP concrete at different ages was determined by the ratio of the strength at each age to the strength at 28 days, as shown in Table 12. 


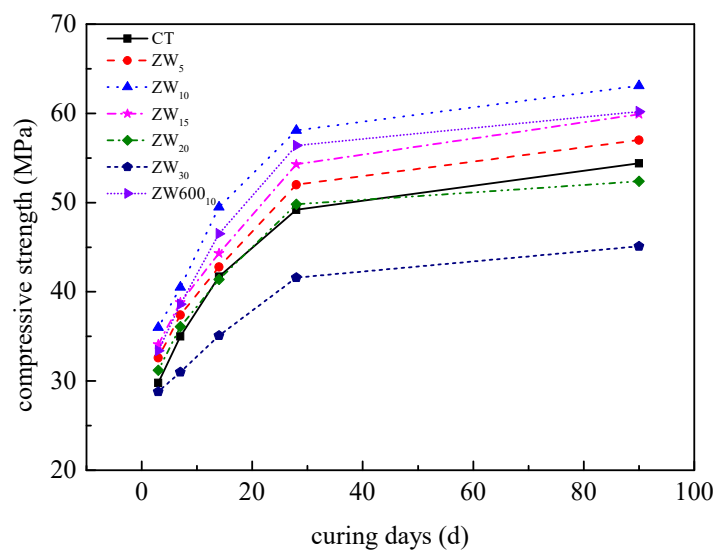

Figure 6. Development curves of compressive strength for concrete with varying CANCP content with age.

Table 12. Relative compressive strength of CANCP concrete with age.

\begin{tabular}{cccccc}
\hline \multirow{2}{*}{ Specimen Name } & \multicolumn{5}{c}{ Curing Days } \\
\cline { 2 - 6 } & 3 Days & 7 Days & 14 Days & 28 Days & 90 Days \\
\hline $\mathrm{CT}$ & 0.604 & 0.711 & 0.846 & 1.000 & 1.104 \\
$\mathrm{ZW}_{5}$ & 0.627 & 0.720 & 0.822 & 1.000 & 1.096 \\
$\mathrm{ZW}_{10}$ & 0.619 & 0.696 & 0.852 & 1.000 & 1.087 \\
$\mathrm{ZW}_{15}$ & 0.628 & 0.716 & 0.816 & 1.000 & 1.104 \\
$Z W_{20}$ & 0.625 & 0.724 & 0.831 & 1.000 & 1.052 \\
$Z W_{30}$ & 0.692 & 0.744 & 0.842 & 1.000 & 1.084 \\
$Z W_{600}$ & 0.592 & 0.684 & 0.824 & 1.000 & 1.067 \\
\hline
\end{tabular}

The ratio of the compressive strength of $\mathrm{CANCP}$ concrete at a certain age to the 28 days compressive strength $\left(\mathrm{f}_{\mathrm{cu}}(\mathrm{t}) / \mathrm{f}_{\mathrm{cu}}(28)\right)$ was defined as the age coefficient of concrete $(\mathrm{Y})$. Using the mathematical model $\mathrm{Y}=\mathrm{A} \ln (\mathrm{T})+\mathrm{B}$, where $\mathrm{A}$ and $\mathrm{B}$ are constants, regression analysis was performed on the relative compressive strength and age of concrete with CANCP content of $5 \%, 10 \%, 15 \%, 20 \%$, and $30 \%$, as shown in Figure 7.

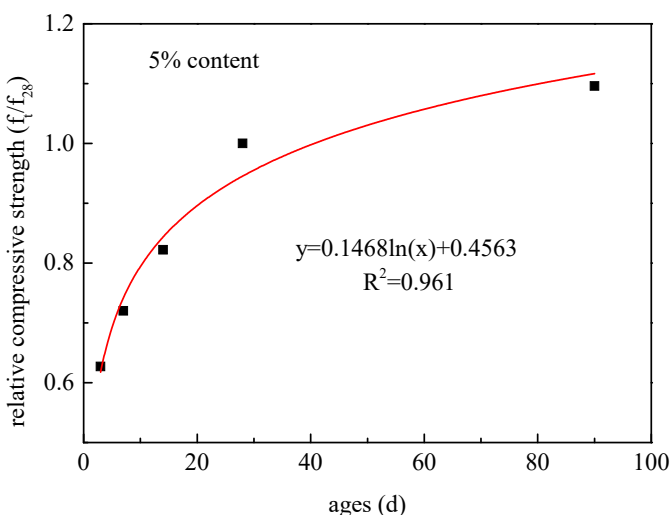

(a)

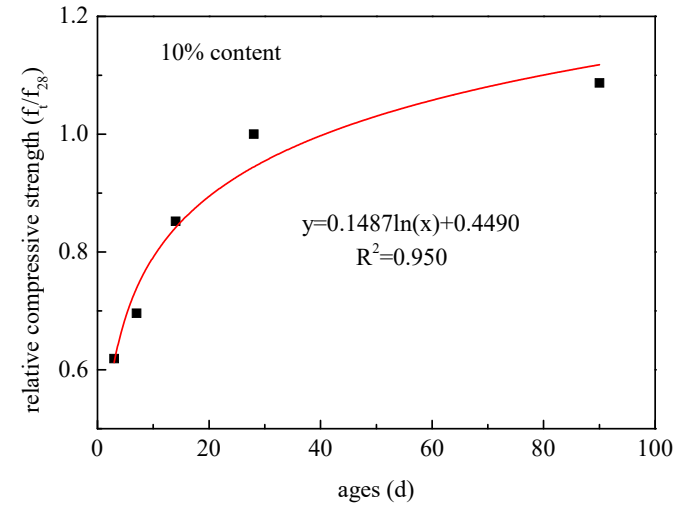

(b)

Figure 7. Cont. 


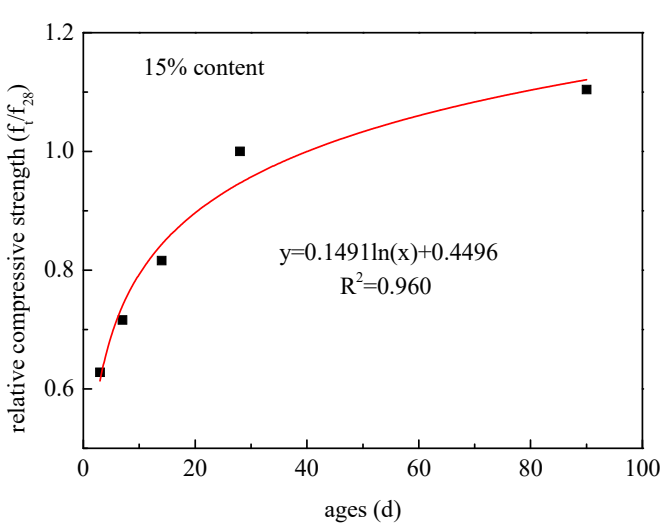

(c)

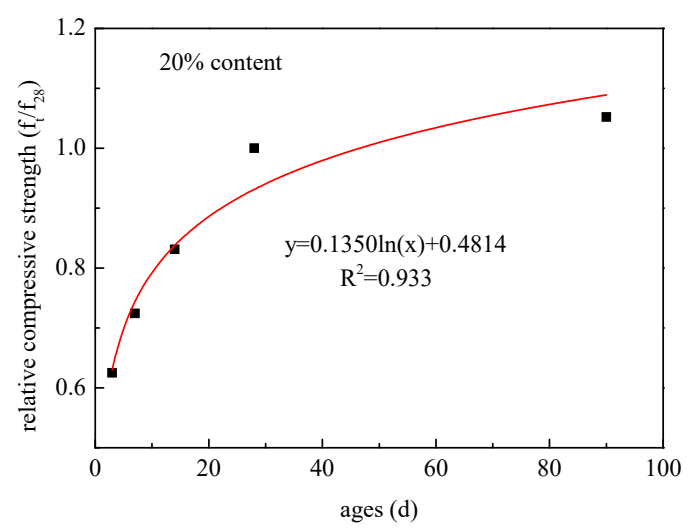

(d)

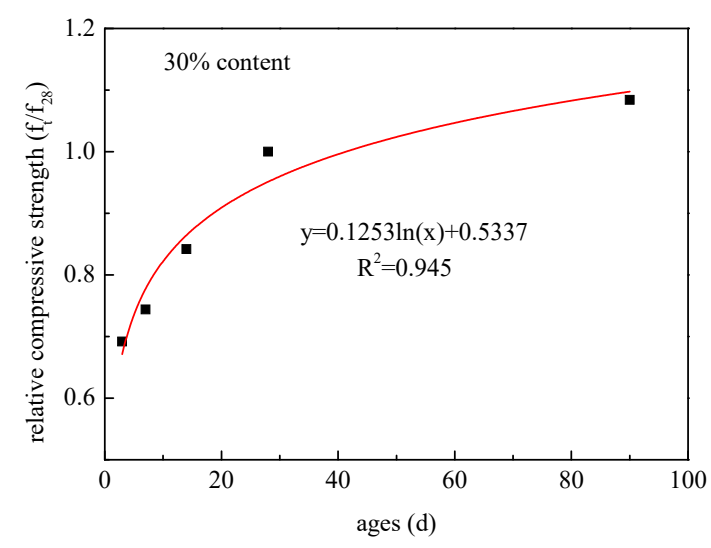

(e)

Figure 7. Regression analysis of relative compressive strength and age of concrete with CANCP content of (a) $5 \%$ (b) $10 \%$ (c) $15 \%$ (d) $20 \%$ and (e) $30 \%$.

As shown in Figure 7, the correlation index $R^{2}$ is greater than 0.93 , and the formula obtained by regression is highly correlated. The A and B values for the $5 \%, 10 \%$ and $15 \%$ content are relatively close, and the correlation index $R^{2}$ is approximately 0.96 . The increase in strength with age is essentially consistent when the CANCP content is not more than $15 \%$.

\subsubsection{Influence of Calcination Temperature}

The optimum content of CANCP with $800{ }^{\circ} \mathrm{C}$ calcination in this experiment is $10 \%$ of the cementitious materials, and therefore, a comparative test of concrete containing $10 \%$ CANCP with $600{ }^{\circ} \mathrm{C}$ calcination was performed. As shown in Figure 6, the compressive strength of the concrete containing $10 \%$ CANCP with $600{ }^{\circ} \mathrm{C}$ calcination is higher than that of the reference concrete CT; all ages increased by more than $10 \%$, and the strength at 28 days increased by $14.6 \%$. The strength of all ages decreased by approximately $5 \%$ relative to the compressive strength of the concrete containing $10 \%$ CANCP with $800^{\circ} \mathrm{C}$ calcination.

The CANCP with $600^{\circ} \mathrm{C}$ calcination was ground in the same conditions; thus, its fineness was essentially identical to the CANCP with $800{ }^{\circ} \mathrm{C}$ calcination and had the same filling effect. Therefore, the test proved that the active component and activity index of CANCP with $800{ }^{\circ} \mathrm{C}$ calcination is higher than that with $600{ }^{\circ} \mathrm{C}$ calcination. The nest soil is similar to kaolin clay from the analysis of the soil chemical composition, and the differential thermal curve of general kaolin clay is a smooth curve between $700{ }^{\circ} \mathrm{C}$ and $800{ }^{\circ} \mathrm{C}$. This finding shows that the thermal effect is low in this temperature range and that the activity is highest at this time [42]. 


\subsubsection{Analysis of Mechanism of Action of CANCP in Concrete}

The action mechanism of CANCP in concrete can be explained by the three microstructural phases of concrete, which are hydrated cement paste, aggregate, and the interfacial transition zone between cement paste and aggregate. The influence of the interfacial transition zone on the mechanical properties of concrete is much greater than that of other factors [43]. Interfacial adhesion is the key to determining the strength of concrete, and this adhesion depends on the hydration products of cement. The most influential product is C-S-H gel, followed by $\mathrm{Ca}(\mathrm{OH})_{2}$. C-S-H gel has a small particle size, large specific surface area, high surface energy and high interfacial bond strength. C-S-H gel has a decisive influence on the concrete strength. $\mathrm{Ca}(\mathrm{OH})_{2}$ crystallizes as plates with a large size, small specific surface area, low surface energy, weak interfacial bonding, and a simple orientation arrangement on the surface of the aggregate. $\mathrm{Ca}(\mathrm{OH})_{2}$ acts as an isolation effect between the C-S-H gel and the aggregate and plays a negative role in interfacial adhesion. To increase the strength of concrete, the amount of C-S-H gel should be increased, and the amount of $\mathrm{Ca}(\mathrm{OH})_{2}$ should be reduced [43]. Figure 8 shows SEM micrographs of ordinary concrete CT and 10\% CANCP concrete at 28 days curing under different magnifications.

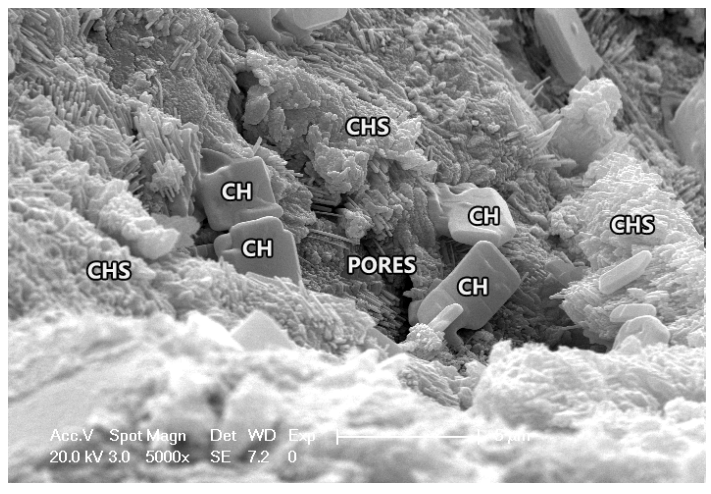

(a)

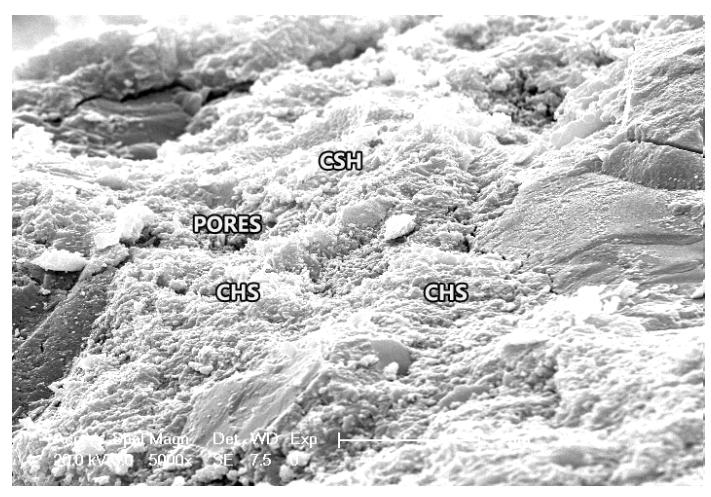

(b)

Figure 8. (a) 5000 $\times$ ordinary concrete (28 days curing) and (b) $5000 \times 10 \%$ CANCP concrete (28 days curing) SEM micrographs.

CANCP has strong pozzolanic activity. The amorphous $\mathrm{Al}_{2} \mathrm{O}_{3}$ and $\mathrm{SiO}_{2}$ formed by the removal of hydroxyl groups can undergo a second hydration reaction with the cement hydration product $\mathrm{Ca}(\mathrm{OH})_{2}$, and this reaction, called the pozzolanic reaction, can generate C-S-H gel. During the pozzolanic reaction, $\mathrm{Ca}(\mathrm{OH})_{2}$ in the hydrated cement paste is consumed, and the amount of C-S-H gel increases. CANCP can also react with the hydration product C-S-H gel in the hydrated cement paste to create additional C-S-H called the pozzolanic C-S-H gel. The composition and properties of pozzolanic C-S-H gel and traditional C-S-H gel are different; the latter is relatively stable after polymerization with $\mathrm{OH}^{-}$ and $\mathrm{Al}^{2+}$ and can improve the performance of the traditional C-S-H gel to improve the performance of cement mortar, therefore improving the compressive strength of concrete. In Figure $8 \mathrm{~b}$, under a high-power electron microscope, C-S-H gel in concrete containing 10\% CANCP is observed to grow dense and clustered to a higher degree than ordinary concrete. In addition, concrete containing $10 \%$ CANCP has a high degree of hydration.

The product of reactions between CANCP and concrete can improve the interface structure between cement paste and aggregate. A large amount of $\mathrm{Ca}(\mathrm{OH})_{2}$ exists in the interface area of concrete, which makes the interface a weak area. $\mathrm{CANCP}$ has a large specific surface area and a large surface energy and can rapidly react with $\mathrm{Ca}(\mathrm{OH})_{2}$ for secondary hydration reactions, reducing the content of $\mathrm{Ca}(\mathrm{OH})_{2}$ in the interface region, also decreasing the crystal size of $\mathrm{Ca}(\mathrm{OH})_{2}$ [44]. Therefore, the weak zone of the interface area is filled with hydration products and increases the strength. As shown in Figure 8 via high-power electron microscopy, a large amount of flake $\mathrm{Ca}(\mathrm{OH})_{2}$ is found in the hydrated 
cement paste of the ordinary concrete, but $\mathrm{Ca}(\mathrm{OH})_{2}$ is not found in the cement hydration paste of concrete containing $10 \%$ CANCP. CANCP can react with $\mathrm{Ca}(\mathrm{OH})_{2}$ for secondary hydration reactions and can consume the content of $\mathrm{Ca}(\mathrm{OH})_{2}$ in the interface region.

The average particle size of CANCP is $23.35 \mu \mathrm{m}$, making it a relatively fine powder particle. Concrete is a granular accumulation system with continuous gradation, and the voids of each aggregate are filled with graded particles smaller than the voids. CANCP particles fill a wide range and can fill the fine pores in hardened cement paste, reducing the porosity of the paste. However, hydration reactions can produce hydrated calcium silicate and calcium sulphoaluminate hydrate with the filling effect and can optimize the internal pore structure of concrete, making the hardened cement paste and concrete stronger and denser. The hydration reactions can also strengthen the hardened cement paste and concrete to be more resistant to external deformation. Under low-magnification electron microscopy, the inner holes of the ordinary concrete are more numerous and are larger, and the surface morphology is not smooth or loose. Instead, there are few holes in the concrete containing 10\% CANCP, and its surface is flat and dense.

\section{Conclusions}

The results of experimental studies on calcined underground ant nest materials were presented, and the following conclusions were drawn:

1. The results of chemical composition analysis indicate that the total contents of $\mathrm{SiO}_{2}, \mathrm{Al}_{2} \mathrm{O}_{3}$ and $\mathrm{Fe}_{2} \mathrm{O}_{3}$ for $800{ }^{\circ} \mathrm{C} \mathrm{CANCP}$ and $600{ }^{\circ} \mathrm{C} \mathrm{CANCP}$ reached $88.76 \%$ and $83.37 \%$, respectively, which are both greater than the $70 \%$ specified in the ASTM standard.

2. It was shown via two methods (the lime absorption method and the strength index method) that CANCP has pozzolanic activity.

3. The strength contribution rate of the pozzolanic effect of mortar CANCP is positive and increases with age. CANCP has a favorable effect on the strength of the mortar system from an early age.

4. The compressive strength of concrete is maximized at $10 \% \mathrm{CANCP}$, and the early strength increases quickly. The compressive strength of concrete containing 20\% CANCP is similar to that of the reference concrete without CANCP. When the content of CANCP is above $20 \%$, the compressive strength of concrete begins to decrease, and the early strength decreases less.

5. The compressive strength of concrete with various CANCP content increases with age, and early strength develops faster. Increased strength is generally consistent with age when the CANCP content is not more than $15 \%$.

6. The compressive strength of concrete containing CANCP with $800^{\circ} \mathrm{C}$ calcination is higher than with calcination at $600^{\circ} \mathrm{C}$. CANCP with $800^{\circ} \mathrm{C}$ calcination thus shows superior pozzolanic activity.

7. CANCP can improve the strength of mortar and concrete mainly because it can accelerate the hydration of cement and exhibits the pozzolanic and filling effects. Accelerating cement hydration and the pozzolanic effect is important for improving the strength of mortar and concrete, to which the filling effect also contributes in a secondary manner.

Author Contributions: This research project was conceived and performed under supervision of W.Q.; W.Z. and P.Z. designed the experiments; W.Z. performed the experiments, analyzed the results, and structured the manuscript. All authors contributed in the review of the manuscript.

Funding: This research was funded by the National Natural Science Foundation of China, grant number 51678430.

Acknowledgments: Special thanks are extended to Xinqi Mao at Tongji University, China.

Conflicts of Interest: The authors declare no conflict of interest.

\section{References}

1. Elinwa, A.U. Experimental characterization of Portland cement-calcined soldier-ant mound clay cement mortar and concrete. Constr. Build. Mater. 2006, 20, 754-760. [CrossRef] 
2. Barger, G.S.; Hansen, E.R.; Wood, M.R.; Neary, T. Production and use of calcined natural pozzolans in concrete. Cem. Concr. Aggreg. 2001, 23, 73-80.

3. Tironi, A.; Trezza, M.A.; Scian, A.N.; Irassar, E.F. Assessment of pozzolanic activity of different calcined clays. Cem. Concr. Compos. 2013, 37, 319-327. [CrossRef]

4. Shao, Y.; Lefort, T.; Moras, S.; Rodriguez, D. Studies on concrete containing ground waste glass. Cem. Concr. Res. 2000, 30, 91-100. [CrossRef]

5. Ay, N.; Ünal, M. The use of waste ceramic tile in cement production. Cem. Concr. Res. 2000, 30, 497-499. [CrossRef]

6. O'farrell, M.; Wild, S.; Sabir, B.B. Pore size distribution and compressive strength of waste clay brick mortar. Cem. Concr. Compos. 2001, 23, 81-91. [CrossRef]

7. Sabir, B.B.; Wild, S.; Bai, J. Metakaolin and calcined clays as pozzolans for concrete: A review. Cem. Concr. Compos. 2001, 23, 441-454. [CrossRef]

8. Mohammed, S. Processing, effect and reactivity assessment of artificial pozzolans obtained from clays and clay wastes: A review. Constr. Build. Mater. 2017, 140, 10-19. [CrossRef]

9. Mikanovic, N.; Hoffeins, M.; Rosani, D.; Hauschildt, I. Calcined natural clays: Performance evaluation as cementitious material. Calcined Clays Sustain. Concr. 2015, 10, 593. [CrossRef]

10. Petal, J. Production Ecology of Ants and Termites; Cambridge University Press: Cambridge, UK, 1978.

11. Coventry, R.J.; Holt, J.A.; Sinclair, D.F. Nutrient cycling by mound-building termites in low-fertility soils of semi-arid tropical Australia. Soil Res. 1988, 26, 375-390. [CrossRef]

12. Jungerius, P.D.; van den Ancker, J.A.M.; Mucher, H.J. The contribution of termites to the microgranular structure of soils on the Uasin Gishu Plateau, Kenya. Catena 1999, 35, 349-363. [CrossRef]

13. Majer, J.D.; Walker, T.C.; Berlandier, F. The role of ants in degraded soils within Dryandra State Forest. Mulga Res. J. 1987, 9, 15-16.

14. Boxer, F.P.; Hole, F.B. Ant (Formica cinerea) pedoturbation in a prairie soil. Soil Sci. Soc. Am. J. 1967, 31, 425-428.

15. Mcgarry, D.; Bridge, B.J.; Radford, B.J. Contrasting soil physical properties after zero and traditional tillage of an alluvial soil in the semi-arid subtropics. Soil Tillage Res. 2000, 53, 105-115. [CrossRef]

16. Mandel, R.D.; Sorenson, C.J. The role of the western harvester ant (Pogonomyrmex occidentalis) in soil formation soil mixing, ant mounds. J. Soil Sci. Soc. Am. 1982, 46. [CrossRef]

17. Dauber, J.; Rommeler, A.; Wolters, V. The ant lasius flavus alters the viable seed bank in pastures. Eur. J. Soil Biol. 2006, 42, S157-S163. [CrossRef]

18. Jílková, V.; Šebek, O.; Frouz, J. Mechanisms of pH change in wood ant (Formica polyctena) nests. Pedobiologia 2012, 55, 247-251. [CrossRef]

19. Geiger, S.C.; Manu, A.; Bationo, A. Changes in a sandy Sahelian soil following crop residue and fertilizer additions. Soil Sci. Soc. Am. J. 1992, 56, 172-177. [CrossRef]

20. Garnier-Sillam, E.; Toutain, F. Distribution of polysaccha-rides within the humic compounds of soils subjected to a humivorous termite thoracotermes macrothorax sjostedt. Pedobiologia 1995, 39, 462-469.

21. Jílková, V.; Frouz, J. Contribution of ant and microbial respiration to $\mathrm{CO}_{2}$ emission from wood ant (Formica polyctena) nests. Eur. J. Soil Biol. 2014, 60, 44-48. [CrossRef]

22. Abbadie, L.; Lepage, M. The role of subterranean fungus comb chambers (isoptera, macrotermitinae) in soil nitrogen cycling in a preforest savanna (côte divoire). Soil Biol. Biochem. 1989, 21, 1067-1071. [CrossRef]

23. Lilburn, T.C.; Kim, K.S.; Ostrom, N.E. Nitrogen fixation by symbiotic and free-living spirochetes. Science 2001, 292, 2495-2498. [CrossRef]

24. Samet, B.; Mnif, T.; Chaabouni, M. Use of a kaolinitic clay as a pozzolanic material for cements: Formulation of blended cement. Cem. Concr. Compos. 2007, 29, 741-749. [CrossRef]

25. Badogiannis, E.; Kakali, G.; Tsivilis, S. Metakaolin as supplementary cementitious material-optimization of kaolin to metakaolin conversion. J. Therm. Anal. Calorim. 2005, 81, 457-462. [CrossRef]

26. ASTM C311-11b. Standard Test Methods for Sampling and Testing Fly Ash or Natural Pozzolans for Use in Portland-Cement Concrete; ASTM International: West Conshohocken, PA, USA, 2011.

27. Amin, M.S.; Abo-El-Enein, S.A.; Rahman, A.A.; Alfalous, K.A. Artificial pozzolanic cement pastes containing burnt clay with and without silica fume. J. Therm. Anal. Calorim. 2012, 107, 1105-1115. [CrossRef]

28. Lixi, H.; Beihai, H.; Lihong, Z. Study on the calcining of water washed kaolin and its product properties. Pap. Sci. Technol. 2010, 4, 35-39. (In Chinese) 
29. Tong, S. Study on the optimum process parameters for the preparation of highly active metakaolin. China Cem. 2013, 12, 94-95. (In Chinese)

30. Zhihua, L.; Yuanfeng, L.; Jiujun, Y. Experimental reseach on properties of raw soil modified by geopolymeric cement. Bull. Chin. Ceram. Soc. 2016, 1, 73-77. (In Chinese)

31. Fly Ash Used for Cement and Concrete; GB/T 1596-2017; Standards Press of China: Beijing, China, 2017.

32. BS EN 196-5:2011. Methods of Testing Cement. Pozzolanicity Test for Pozzolanic Cement; BSI Standards Publication: London, UK, 2011.

33. Rahhal, V.; Talero, R. Influence of two different fly ashes on the hydration of Portland cements. J. Therm. Anal. Calorim. 2004, 78, 191-205. [CrossRef]

34. Talero, R. Performance of metakaolin and Portland cements in ettringite formation as determined by ASTM C 452-68: Kinetic and morphological differences. Cem. Concr. Res. 2005, 35, 1269-1284. [CrossRef]

35. Wild, S.; Gailius, A.; Hansen, H. Pozzolanic properties of a variety of European clay bricks-Comparative study of pozzolanic, chemical and physical properties of clay bricks in four European countries for utilization of pulverized waste clay brick in production of mortar and concrete. Build. Res. Inf. 1997, 25, 170-175. [CrossRef]

36. Mineral Admixtures for High Strength and High Performance Concrete; GB/T18736-2002; Standards Press of China: Beijing, China, 2002.

37. Common Portland Cement; GB175-2007; Standards Press of China: Beijing, China, 2007.

38. Method of Testing Cements-Determination of Strength (ISO Method); GB/T 17671-1999; Standards Press of China: Beijing, China, 1999.

39. Pozzolanic Materials Used for Cement Production; GB/T 2847-2005; Standards Press of China: Beijing, China, 2005.

40. Xincheng, P. Super High Strength High Performance Concrete; Chongqing University Press: Chongqing, China, 2004. (In Chinese)

41. Standard for Test Method of Mechanical Properties on Ordinary Concrete; GB/T 50081-2002; Standards Press of China: Beijing, China, 2002.

42. Kun, L.; Tongjiang, P.; Hongjuan, S. The factorial experiment on activity of calcined kaolinite. Multipurp. Util. Miner. Resour. 2003, 6, 17-20. (In Chinese)

43. Monteiro, P.J.M. Concrete: Microstructure, Properties and Materials; McGraw-Hill Education: New York, NY, USA, 2014.

44. Ziling, X.; Xian, L. Effect of curing temperature and curing time on compressive strength of fly ash geopolymer concrete. Concrete 2014, 6, 55-58. (In Chinese) 